\title{
Soil conservation management with cover crops: effects on critical energy levels, release and dispersion of aggregates
}

Érika Andressa da Silva ${ }^{1, *}$, Dalvan José Reinert², José Miguel Reichert², Micael Stolben Mallmann², Monike Andrade Pereira², Sarah Severo Pons², William Saidelles Foggiato ${ }^{2}$

1.Universidade Federal de Lavras - Departamento de Solos - Lavras (MG), Brazil.

2.Universidade Federal de Santa Maria - Departamento de Solos - Santa Maria (RS), Brazil.

ABSTRACT: The normalized dispersion index (NDI) and the b/a index are commonly used to express the stability of aggregates measured by ultrasound. However, few studies have used the critical energy (CE) extracted from modeling to explain the effects of soil use and management on soil aggregation. The objective of this study was to evaluate the influence of soil cover on the CE level required for dispersion of aggregates of a Typic Hapludalf. Soil samples collected from the 0.0-0.05 $\mathrm{m}$ depth were evaluated in five different managements with cover plants: perennial soybean (PS), peanuts (P), spontaneous vegetation (SV), black oat/forage turnip (BOFT), and black oat/hairy vetch (BOHV). Aggregates $\leq 2 \mathrm{~mm}$ of the treatments were exposed to ultrasonic irradiation during $0,30,60,120$ and $180 \mathrm{~s}$. The specific applied energies were calculated based on sonification time and potency: $0,745,1490,2980$, and $4470 \mathrm{~J} \cdot \mathrm{g}^{-1}$. After each sonification, sand (2000-53 $\mu \mathrm{m})$, silt (53-2 $\mu \mathrm{m})$ and clay $(<2 \mu \mathrm{m})$ were quantified. The mass of aggregates of each size class was modeled as a function of the ultrasonic energy. The CE, the NDI and the b/a indexes were coefficients extracted from these models. Cover crops influenced the critical energy levels required for dispersion of aggregates of the Typic Hapludalf. However, our methodology did not prove management systems with intercrops of the cover crops, as black oats and vetch, contribute more effectively to the increase of soil aggregation.

Key words: ultrasonic dispersion, aggregation models, leguminous, grasses. 


\section{INTRODUCTION}

The description of soil particles interaction resulted in the development of concepts and models that describe a hierarchical system of aggregation. Smaller aggregates, denominated microaggregates $(<250 \mu \mathrm{m})$, are formed from the union of primary particles and silt-sized aggregates by organic and inorganic resistant bonding agents, such as organic matter, silicate clays, polyvalent cations, oxides and aluminosilicates. Moreover, macroaggregates (> $250 \mu \mathrm{m}$ ) originate from the union of microaggregates conditioned by temporary (fungal roots or hyphae) and transients (polysaccharides derived from microorganisms or plants) cementing agents (Tisdall and Oades 1982).

Considering different binding agents form aggregates of distinct sizes, the aggregate hierarchy theory postulates that the level of energy required to promoting the disaggregation, and consequently the complete dispersion of the soil aggregates, is linked to the interactions between cementing agents and soil mineral particles (Kaiser and Berhe 2014; Zhu et al. 2017). By using ultrasound, it is possible to quantify the energy required for dispersion of the aggregates in each size scale (Schomakers et al. 2011), which makes it possible to model the redistribution of particles as a function of the applied energy level (Zhu et al. 2009a; 2009b; 2010).

Based on these principles, Field et al. (2006) demonstrated to the possibility of predicting the existence of hierarchy of aggregates in soils from the modeling of the disaggregation and dispersion of aggregates ranging from 2000 to $2 \mu \mathrm{m}$. According to the models, the behavior of sand-sized aggregates (2000-53 $\mu \mathrm{m})$ can be described by an aggregate-disruption characteristic curve (ADCC), in which the quantity of sandsized aggregates decreases exponentially with the increase of the applied energy (Ribeiro et al. 2013). Disaggregation and release of silt-sized aggregates can be understood by the releasing of aggregate and dispersion curve (RADC), while aggregates in the clay fraction are represented by soildispersion characteristic curve (SDCC). It was confirmed that there is a hierarchy between the fractions of aggregates when the disintegration constant extracted from the ADCC is greater than the dispersion constant obtained by the SDCC.

The critical energy required for the total release of the siltsized aggregates and the beginning of their dispersion can be calculated from the ADCC and SDCC curves. High values of this critical energy are related to a greater structural stability of the aggregates (Zhu et al. 2009a; 2009b; 2010). Ribeiro et al. (2013) observed that vinasse application increased the amount of energy necessary to disperse the aggregates by reducing the disaggregation and dispersion constants in an Oxisol and an Ultisol.

In a recent study, Zhu et al. (2017) used coefficients extracted from ADCC and SDCC to measure the effects of different plant residues on soil aggregation, and observed the quality of the added residue (greater recalcitrance or greater lability) altered the energy levels required to cause the dispersion and release of aggregates.

Studies show organic compounds from the decomposition of leguminous plants remains comprised cementing substances of greater lability, which means they degrade more easily than the products derived from grass decomposition (Acosta et al. 2014; Aita and Giacomini 2003).

In Brazil, the normalized dispersion index and $\mathrm{b} / \mathrm{a}$ index have been used to express the stability of aggregate measured by ultrasound (Sá et al. 1999; Silva et al. 2016). The normalized dispersion indexes relate the content of dispersed silt/clay particles and the released aggregates to a specific energy level, and $b / a$ index is found from the linearization of the soil dispersion curves (Sá et al. 1999). However, few studies have used modeling coefficients, such as the critical energy, to explain the effects of land use and management on aggregation (Ribeiro et al. 2013). Considering the results observed by Zhu et al. (2017), there is an expectation cover plants used in management systems are promoting changes in soil aggregation. It is expected that management systems with intercrops of the cover crops, as black oats and vetch, can contribute more effectively to the increase of soil aggregation than those management systems with leguminous monocultures. Therefore, the aim of this study was to evaluate the influence of cover crops on the critical energy levels required for dispersion of aggregates of a Typic Hapludalf.

\section{MATERIAL AND METHODS Description of the experimental area}

The study was carried out on a Typic Hapludalf (Soil Taxonomy) presenting sandy loam texture up to $40 \mathrm{~cm}$ deep, in an area of the Federal University of Santa Maria, Santa Maria, Rio Grande do Sul state $\left(29^{\circ} 68^{\prime}\right.$ S, $53^{\circ} 81^{\prime}$ W).

The climate of the region defined as Cfa according to the classification of Köppen, which corresponds to a humid 
subtropical climate without droughts and total annual precipitation of approximately $1708 \mathrm{~mm}$. The average annual temperature of Santa Maria is $19.2{ }^{\circ} \mathrm{C}$ and the average temperature of the coldest month is $13.8^{\circ} \mathrm{C}$.

The experiment was carried out in a randomized block design, consisting of five treatments and four replicates. The treatments consisted of different cover crops in association with the main crop (Yerba mate). The cover plants used were: perennial soybean $(\mathrm{PS})$, peanuts $(\mathrm{P})$, spontaneous vegetation (SV), black oat + forage turnip (BOFT), and black oat + hairy vetch (BOHV).

Before the installation of the experiment, the soil was tilled using a tractor (Massey Ferguson 275). From November 20 to 27 , the cover crops were sown and the perennial soybean (Neonotonia wightii) was planted using a $6 \mathrm{~kg}$ seeds $\cdot \mathrm{ha}^{-1}$. The forage peanut (Arachis pintoi) was planted in $0.25-\mathrm{m}$ spaced rows. The weeds were manually removed.

In the BOFT treatment, black oats (Avena strigosa) + forage turnip (Raphanus sativus) were cultivated in autumn/ winter and beans (Vigna unguiculata) in the spring/summer. The black oats and turnip were sown considering $30 \%$ and $70 \%$ of the seed recommendation per hectare (Giacomini et al. 2004), respectively.

The BOHV treatment consists of black oats (Avena strigosa) + vetch (Vicia sativa L.) grown in autumn/winter and beans (Vigna unguiculata) in spring/summer. Black oats and vetches were sown at $45 \%$ and $55 \%$ of the total seed recommendation per hectare (Giacomini et al. 2004), respectively.

On November 20, 2014, bean seeds were manually sown in the grooves of treatments BOFT and BOHV using $60 \mathrm{~kg}$ seeds $\cdot \mathrm{ha}^{-1}$, which is equivalent to 12 seeds per linear meter, in approximately $10 \mathrm{~cm}$ of soil depth and with spacing of $0.40 \mathrm{~m}$. The weeds were manually removed.

In April 14, prior to the manual planting of black oats, forage turnips, vetches, and bean plants were removed. The second planting of beans was carried out on the black oats, forage turnip and vetch straws, on November 15. Firstly, manual weeding of winter crops was carried out for later planting of the beans with the use of a hand planter.

Yerba Mate seedlings were manually planted in the field on December 9, 2014 with spacing of $2.0 \times 2.5 \mathrm{~m}$, using 35 plants in each experimental unit.

Urea ( $45 \mathrm{~g})$, superphosphate $(56 \mathrm{~g})$ and potassium chloride (17 g) were applied based on the Brazilian Society of Soil Science - Soil Chemistry and Soil Fertility Commission
RS/SC 2004. The fertilizers were mixed with the soil and placed in four pits near the seedling.

A wooden blade ( $3 \mathrm{~mm}$ thick $\times 40 \mathrm{~cm}$ high) was placed in each seedling in the west position to avoid the afternoon sun, leaving the other positions free to receive sunlight. These blades were removed after 6 months. The dead seeds were replanted.

To avoid weeds, seedlings crowning was performed periodically. In the first years of cultivation ( 1 to 3 years) the experiment was irrigated according to the need of the crops. A sprinkler system with six sprinklers arranged linearly at every $12 \mathrm{~m}$ was used, so that all the experimental units were irrigated with the same amount of water.

Before the installation of the experiment, the $0.0-0.05 \mathrm{~m}$ layer presented the following chemical characteristics: $\mathrm{pH}$ (water) of 5.2, soil organic matter $2 \mathrm{dag} \cdot \mathrm{kg}^{-1}$, phosphorous $12.4 \mathrm{mg} \cdot \mathrm{dm}^{-3}$ (Mehlich-1), potassium $69.3 \mathrm{mg} \cdot \mathrm{dm}^{-3}$, calcium $2.3 \mathrm{cmol}_{c} \cdot \mathrm{dm}^{-3}$, magnesium $0.7 \mathrm{cmol}_{c} \cdot \mathrm{dm}^{-3}$ and $\mathrm{H}+\mathrm{Al} 4.5 \mathrm{cmol} \cdot \mathrm{dm}^{-3}$. The chemical characterization for all treatments is shown in Table 1.

Table 1. Chemical characterization for depth $0.0-0.05 \mathrm{~m}$ of the Typic Hapludalf under yerba mate cultivation in association with different cover crops.

\begin{tabular}{ccccccc}
\multirow{2}{*}{ Management } & \multirow{2}{*}{$\mathbf{p H}$} & $\mathbf{H + A l}$ & $\mathbf{K}^{+}$ & $\mathbf{C a}^{2+}$ & $\mathbf{M g}^{2+}$ & $\mathbf{S O M}$ \\
\cline { 3 - 6 } & & \multicolumn{5}{c}{$\mathbf{c m o l}_{\mathbf{c}} \mathbf{d m}^{-3}$} \\
BOFT & 4.70 & 0.34 & 1.03 & 2.81 & 4.60 & 2.20 \\
\hline BOHV & 4.70 & 0.33 & 1.01 & 2.73 & 4.23 & 2.36 \\
\hline PS & 4.93 & 0.15 & 0.97 & 2.86 & 4.47 & 2.46 \\
\hline P & 4.87 & 0.17 & 1.05 & 1.34 & 4.83 & 1.96 \\
\hline SV & 4.97 & 0.37 & 1.22 & 3.09 & 3.40 & 2.35 \\
\hline
\end{tabular}

$\mathrm{BOFT}=$ black oat + forage turnip; $\mathrm{BOHV}=$ black oat + hairy vetch $(\mathrm{BOHV})$; $\mathrm{PS}=$ Perennial soybean; $\mathrm{P}=$ peanuts; $\mathrm{SV}=$ spontaneous vegetation; $\mathrm{SOM}=$ soil organic matter.

\section{Soil disaggregation quantification and modeling}

Soil samples were collected in the third year of the experiment (2017), which was implemented in 2014. As of October, in the intercrops systems BOHV and BOFT, the plants begin to dry, and in November the bean is introduced. Later, in April/May, the bean is replaced by BOHV or BOFT, according to the experimental design.

Thus, soil sampling for aggregation evaluation was carried out at the end of September, when the intercrops (1: BOHV and 2: BOFT) and monocultures (P, PS) totally covered the soil. Samples of the 0-5-cm layer were collected in the center 
of each experimental unit. Each sample was dried, ground and passed through a 2-mm sieve. A total of $3 \mathrm{~g}$ of aggregates of the fraction $<2 \mathrm{~mm}$ (oven dry basis) were sonicated in $50 \mathrm{~mL}$ of distilled water for $30,60,120$, and $180 \mathrm{~s}$.

A Vibra-Cell ${ }^{\text {tw }}$ Ultrasonic (model VCX-750) equipped with a titanium rod $(19,1 \mathrm{~mm}$ in diameter and $40 \mu \mathrm{m}$ of amplitude) with a power of $74.5 \mathrm{~W}$ was used (Ribeiro et al. 2017). Based on the sonification times and the potency, the ultrasonic energy values were calculated by Eq. 1:

$$
\mathrm{UE}=\mathrm{P} \times \mathrm{T} / \mathrm{M}
$$

where UE is the ultrasonic energy applied $\left(\mathrm{J} \cdot \mathrm{g}^{-1}\right) ; \mathrm{P}$ is the potency $(\mathrm{W})$ emitted by the apparatus and calculated by calibration; $\mathrm{T}$ is the sonification time (s); and $\mathrm{M}$ is the mass of aggregates (g).

Each sonification time corresponds to the applied specific

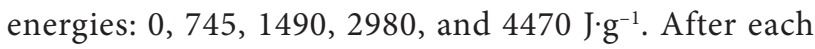
sonification, the sand-sized aggregates retained in the $53-\mu \mathrm{m}$ sieve were quantified, while the silt-size and the clay aggregates were transferred to a $1000 \mathrm{~mL}$ measuring cylinder. The volume of the cylinder was completed with distilled water and the suspension was shaken. Based on Stokes' law, the sedimentation time of the silt-size aggregates $(3 \mathrm{~h})$ was calculated. After the sedimentation time, an aliquot of $25 \mathrm{~mL}$ of the suspension containing particles of clay size was collected using an automatic volumetric pipette. The clay aliquots were oven dried for $24 \mathrm{~h}$, and weighted to quantify the clay aggregates.

The quantification of the silt-sized aggregates was performed by difference, considering that the sum of the sand (2000-53 $\mu \mathrm{m})$, silt $(53-2 \mu \mathrm{m})$ and clay $(<2 \mu \mathrm{m})$ fractions is equal to 1 . The determined values of each fraction were adjusted to the models proposed by Field and Minasny (1999) and Field et al. (2006) and adapted to Brazilian soils by Ribeiro et al. (2013). The aggregate-disruption characteristic curve (ADCC), the soil-dispersion characteristic curve (SDCC) and the releasing of aggregate and dispersion curve (RADC) were modeled according to Eqs. 2, 3, and 4, respectively.

$$
\mathrm{ADCC}=\mathrm{y}_{0}+\mathrm{a}_{1} \cdot \exp \left(-{ }_{1}^{\mathrm{K}} \mathrm{x}\right)
$$

where ADCC represents the 53 to $2000 \mu \mathrm{m}$ aggregate size or sand fraction in a given ultrasonic energy level $(\mathrm{x}) ; \mathrm{y}_{0}, \mathrm{a}_{1}$ and $\mathrm{k}_{1}$ are fitting coefficients; $\mathrm{k}_{1}$ is referenced as a disaggregation constant $\left(\mathrm{g} \cdot \mathrm{J}^{-1}\right)$.

$$
\mathrm{SDCC}=\mathrm{a}_{2}\left[1-\exp \left(-\mathrm{kx}_{2}\right)\right]
$$

where SDCC is the clay fraction $(<2 \mu \mathrm{m})$ dispersed using a given ultrasonic energy level ( $\mathrm{x}$ ); a and $\mathrm{k}_{2}$ are the fitting coefficients; $\mathrm{k}_{2}$ represents a dispersion constant $\left(\mathrm{g} \cdot \mathrm{J}^{-1}\right)$, according to Field and Minasny (1999) and Field et al. (2006).

$$
\mathrm{RADC}=1-\left[\mathrm{y}_{0}+\mathrm{a}_{1} \cdot \exp \left(-{ }_{1}^{\mathrm{k} \mathrm{x}}\right)+\mathrm{a}_{2}\left(1-\exp \left(-\mathrm{k}_{2} \mathrm{x}\right)\right]\right.
$$

where RADC is the 2 to $53 \mu \mathrm{m}$ aggregate size or silt-size fraction in a given ultrasonic energy level $(\mathrm{x}) ; \mathrm{y}_{0}, \mathrm{a}_{1}$ and $\mathrm{a}_{2}$ are the fitting coefficients of the model; $\mathrm{k}_{1}$ is the disaggregation constant; and $\mathrm{k}_{2}$ is the dispersion constant.

With these models, the critical energy (CE) was calculated for the beginning of the dispersion of the aggregates by Eq. 5:

$$
\mathrm{CE}=\operatorname{In}(k 2 / \mathrm{k} 1) / \mathrm{k} 2-\mathrm{k} 1
$$

Based on the material retained in the $53-\mu \mathrm{m}$ sieve (which was oven dried for $24 \mathrm{~h}$ at $105^{\circ} \mathrm{C}$ and weighed) and on the solids that passed through the sieve (silt + clay contents), it was possible to calculate the dispersion and disaggregation indexes suggested by Sá et al. (1999). Thus, the dispersion index (DI) was obtained by the following ratio: silt + dispersed clay/initial sample (3 $\mathrm{g}$ of aggregates). The silt + clay was obtained by the difference between the initial sample and what was retained in the $53-\mu \mathrm{m}$ sieve after each sonification time. According to recommendations by Sá et al. (1999), the disaggregation was quantified as a function of sample handling, which represents the zero sonification time. It consisted only in placing the soil in a beaker, filling the volume to $50 \mathrm{~mL}$ with distilled water and immediately passing through the sieve.

The normalized dispersion index (NDI) was calculated by the DI/DI ${ }_{\text {maximum }}$ ratio (Sá et al. 1999). Scattering curves were plotted (applied energy $(\mathrm{X})$, in $\mathrm{J}^{-1}$, versus the normalized dispersion indexes $(\mathrm{Y})$, in $\left.\mathrm{g} \cdot \mathrm{g}^{-1}\right)$. Hyperbolic models of type $\mathrm{Y}=\mathrm{X} /(\mathrm{a}+\mathrm{bX})$ were adjusted and the disaggregation index $\mathrm{b} / \mathrm{a}$ was calculated. The index represents the stability of aggregates based on the behavior of any disaggregation curve.

\section{Statistical analysis}

Randomized block designs with 4 replicates and 5 treatments were used in the experiment. The treatments were compared by five levels of ultrasonic energy, totaling 
100 samples. Data were submitted to analysis of variance and, when pertinent, the means were compared by the Tukey test with 5\% probability using the R software (R Core Team 2014).

\section{RESULTS AND DISCUSSION}

When comparing the behavior of the vegetation cover within each applied specific energy level (Table 2), there were differences between soil management only for the second specific applied energy level $\left(745 \mathrm{~J} \cdot \mathrm{g}^{-1}\right.$, corresponding to $\left.44.4 \mathrm{~J} \cdot \mathrm{mL}^{-1}\right)$. At this energy level, greater soil disaggregation was observed under $\mathrm{P}$ and lower in the soil under BOHV.

Table 2. Normalized dispersion indexes $\left(\mathrm{g} \cdot \mathrm{g}^{-1}\right)$ for a Typic Hapludalf under weed cultivation associated to different conservation management systems with cover plants.

\begin{tabular}{cccccc}
\multirow{2}{*}{ Management } & \multicolumn{6}{c}{ Specific ultrasonic energy levels $\left(\mathbf{J}^{-\mathbf{g}^{-1}}\right)$} \\
\cline { 2 - 6 } & $\mathbf{0}$ & $\mathbf{7 4 5}^{*}$ & $\mathbf{1 4 9 0}$ & $\mathbf{2 9 8 0}$ & $\mathbf{4 4 7 0}$ \\
\hline BOFT & 0.21 & $0.78 \mathrm{ab}$ & 0.88 & 0.94 & 1.0 \\
\hline BOHV & 0.19 & $0.57 \mathrm{~b}$ & 0.78 & 0.90 & 1.0 \\
\hline PS & 0.22 & $0.65 \mathrm{ab}$ & 0.90 & 0.93 & 1.0 \\
\hline P & 0.22 & $0.84 \mathrm{a}$ & 0.93 & 0.97 & 1.0 \\
\hline SV & 0.21 & $0.81 \mathrm{ab}$ & 0.87 & 0.96 & 1.0 \\
\hline
\end{tabular}

$\mathrm{BOFT}$ = black oat + forage turnip; $\mathrm{BOHV}=$ black oat + hairy vetch $(\mathrm{BOHV})$; $\mathrm{PS}=$ Perennial soybean; $\mathrm{P}=$ peanuts; $\mathrm{SV}=$ spontaneous vegetation. ${ }^{*}$ Means followed by the same letter do not differ by the Tukey test $(p<0.05)$.

The $\mathrm{P}$ treatment was the management with the lowest levels of carbon and calcium (Table 1), which may justify its low aggregation. Organic carbon was soil property most correlated with the resistance of the aggregate subjected to ultrasonic irradiation. Calcium contributes to the stabilization of aggregates by forming cationic bridges with clays and soil organic matter (Briedis et al. 2012).

The spontaneous vegetation (SV), even with adequate organic matter and calcium contents, presented similar disaggregation to the management with $\mathrm{P}$. These results show that other factors, such as root configuration, quantity and quality of the organic material synthesized by each crop, and wetting-drying cycles, influenced soil aggregation under these management systems (Tisdall and Oades 1982).

The BOHV and BOFT association favored soil aggregation by influencing the compartments of organic matter in the soil. Vetches and forage turnip favor the contribution of organic compounds of greater lability (Acosta et al. 2014), favoring certain microbiological communities which excrete mucilages and polysaccharides that are ephemeral binding agents important for the formation of macroaggregates in the soil (Tivet et al. 2013).

On the other hand, the plant remains of black oats add to the soil organic compounds of difficult degradation, raising the recalcitrant compartment (Acosta et al. 2014), which plays a more enduring role as a cementing agent of primary soil particles (Zhu et al. 2017). Considering a hierarchical scale of aggregation, for the BOHV and BOFT association, leguminous plant residues may contribute to macroaggregation, while grass residues would act on a microaggregation scale.

Furthernore, when intercropping different species there is production of a phytomass with a $\mathrm{C} / \mathrm{N}$ ratio that is considered intermediate to that of a single crop (Aita and Giacomini 2003; Giacomini et al. 2004; 2003; Doneda et al. 2012). Giacomini et al. (2004) observed a C/N ratio of 18.6 and 23.6 for the BOHV consortium in the years $1999 / 2000$ and 2000/2001, respectively. On the other hand, according to the work of Gama-Rodrigues et al. (2007), the peanuts with a C/N ratio of 15 , reduced quantity lignin and polyphenols (Espindola et al. 2005), exhibit fast mineralization. Therefore, it presents high rates of decomposition, with approximately 50\% dry matter loss in a period of 60 days, and, compared to peanuts, the intercropping cultivation with the BOHV may have provided an increase in the $\mathrm{C} / \mathrm{N}$ ratio of the phytomass, which increased the persistence of cultural residues on the soil surface (Le Guillou et al. 2012; Doneda et al. 2012). As a consequence, the slow and gradual decomposition of the BOHV residues released organic compounds that stimulated the formation and stability of aggregates (Tisdall and Oades 1982).

By contributing to the increase in structural stability, management systems with cover crops favor the physical protection of organic matter. It is incorporated into soil aggregates, becoming less exposed to microbial processes, which results in lower rate of mineralization and $\mathrm{CO}_{2}$ flow into the atmosphere (Lal 2015). In this context, management systems with cover crops, by contributing to carbon sequestration in the soil, become management strategies for a more sustainable agriculture.

In the disaggregation curve for each vegetation cover (Fig. 1), with the exception of the BOHV treatment, normalized disaggregation rates were found very close to or higher than 0.90 when $1490 \mathrm{~J} \cdot \mathrm{g}^{-1}\left(88.8 \mathrm{~J} \cdot \mathrm{mL}^{-1}\right)$ were applied. This shows that the specific energy range to explain the aggregation of this Typic Hapludalf is limited between the energy levels 
of 745 and $1490 \mathrm{~J} \cdot \mathrm{g}^{-1}$. Above this upper limit $\left(1490 \mathrm{~J} \cdot \mathrm{g}^{-1}\right)$, the lines of the hyperbolic models reach a plateau of disaggregation, being no longer possible to verify differences between the treatments.

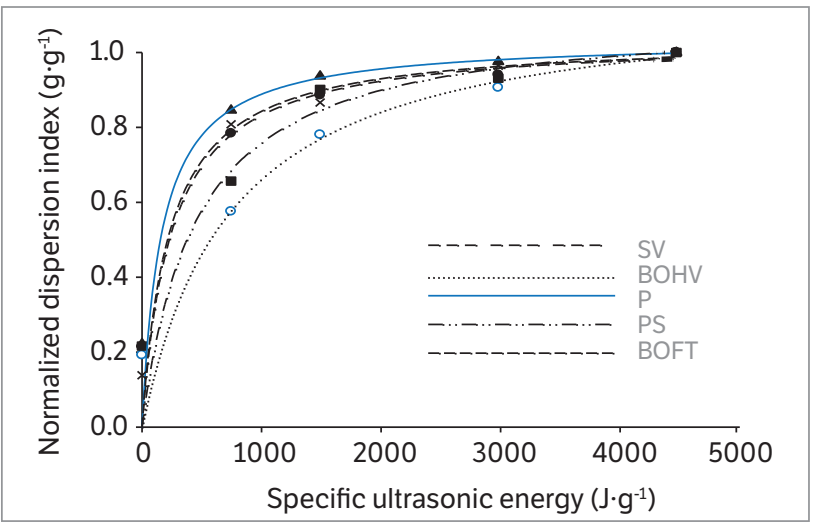

Figure 1. Scatter curves for a Typic Hapludalf under Yerba mate cultivation in association with different cover plants (normalized data, three replicates).

The more stable the treatment, the higher the level of energy required to reach the plateau of the curve (total dispersion). Considering the same soil and horizon (same mineralogy and texture), the dispersion curves are influenced only by the soil management. The effects of soil management can be seen in the upward region of the dispersion curves, where disaggregation occurs (Sá et al. 1999).

Several studies have shown that the disaggregation of cultivated soils requires much lower energy levels compared to that required for soils under non-anthropogenic environments (Schomakers et al. 2011; Silva et al. 2016). Under the conditions of this study, the effects of cover crops on soil aggregation were also reflected in low energy levels, ranging from 0 to $88 \mathrm{~J} \cdot \mathrm{mL}^{-1}$.

When examining the stability of aggregates of an Oxisol under different managements, Sá et al. (2002) observed high sensitivity and small coefficients of variation in the results of dispersion indexes when ultrasonic energies between 30 and $90 \mathrm{~J} \cdot \mathrm{mL}^{-1}$ were applied. The authors pointed out that the best level of energy to determine differences in aggregate stability caused by different soil management was only $36.3 \mathrm{~J} \cdot \mathrm{mL}^{-1}$.

Table 3 shows the adjusted equations for the hyperbolic models that represent the soil dispersion and the disaggregation indexes (b/a) for each vegetation cover. The lower the $b / a$ value, the more stable the soil aggregates. The observed results for the b/a index corroborate with those found by the dispersion indexes. The lowest values, which represent greater stability, were found for the soil managed with $\mathrm{BOHV}$ and PS, while the lowest stability was verified for the soil under the P cultivation.

Table 3. Adjusted equations for normalized dispersion index and index values (b/a) in Typic Hapludalf under yerba mate cultivation in association with different cover crops.

\begin{tabular}{ccc} 
Management & Adjusted equation & $\mathbf{b} / \mathbf{a}^{\star}\left(\mathbf{g} \cdot \mathbf{J}^{-\mathbf{1}}\right)$ \\
\hline $\mathrm{BOFT}$ & $\mathrm{NDI}=\mathrm{UE} /[221.9106+0.9645 \times \mathrm{UE}]$ & $0.0043 \mathrm{bc}$ \\
\hline $\mathrm{BOHV}$ & $\mathrm{NDI}=\mathrm{UE} /[642.4178+0.8667 \times \mathrm{UE}]$ & $0.0013 \mathrm{a}$ \\
\hline $\mathrm{PS}$ & $\mathrm{NDI}=\mathrm{UE} /[412.1905+0.9058 \times \mathrm{UE}]$ & $0.0021 \mathrm{ab}$ \\
\hline $\mathrm{P}$ & $\mathrm{NDI}=\mathrm{UE} /[159.0701+0.9664 \times \mathrm{UE}]$ & $0.0060 \mathrm{~d}$ \\
\hline $\mathrm{SV}$ & $\mathrm{NDI}=\mathrm{UE} /[237.8623+0.964 \times \mathrm{UE}]$ & $0.0040 \mathrm{~cd}$
\end{tabular}

$\mathrm{BOFT}=$ black oat + forage turnip; $\mathrm{BOHV}=$ black oat + hairy vetch $(\mathrm{BOHV}) ; \mathrm{PS}=$ Perennial soybean; $\mathrm{P}=$ peanuts; $\mathrm{SV}=$ spontaneous vegetation; $\mathrm{UE}=$ ultrasonic energy. ${ }^{*}$ Means followed by the same letter in the column do not differ from each other by Tukey test $(p<0.05)$.

Figure 2 shows the adjusted models for soil aggregatedisruption characteristic curve (ADCC), soil-dispersion characteristic curve (SDCC) and the releasing of aggregate and dispersion curve (RADC) of the Typic Hapludalf under cultivation of yerba mate in association with cover plants. The fitted models were significant $(\mathrm{P}<0.0001)$ and the coefficients of determination ranged from 0.94 to 0.99 .

In our study, similar to Ribeiro et al. (2013), soil management improved soil disintegration behavior, promoting reduction or increase of critical energy levels (Table 4) required to cause total dispersion and release of aggregates. Zhu et al. (2017) demonstrated that CE levels were altered due to soil incubation with different organic wastes, and the disintegration $\left(\mathrm{k}_{1}\right)$ and dispersion $\left(\mathrm{k}_{2}\right)$ constants reduced with the increase of the carbon input by the crop residues. Higher energy levels were required to cause disaggregation and release of discrete particle aggregates.

The CE values showed a stability sequence that decreases in the following order: $\mathrm{BOHV}>\mathrm{PS}>\mathrm{BOFT}>\mathrm{SV}>\mathrm{P}$. Thus, in relation to the $\mathrm{b} / \mathrm{a}$ index, it was verified that the CE parameter is more sensitive for treatment distinction than for structural stability aspects (Tables 3 and 4). The CE is a more appropriate parameter to point out differences in soil structural stability because it is based on the individual quantification of aggregates and the size particles sand, silt and clay. The b/a index comes from the coefficients of the equations of the linearized index models of dispersion, which are obtained from the ratio of particle $<0.053 \mathrm{~mm} / \mathrm{mass}$ of initial aggregates, in which the clay 
content is not quantified separately from the silt content (Sá et al. 1999). Therefore, the b/a index does not allow

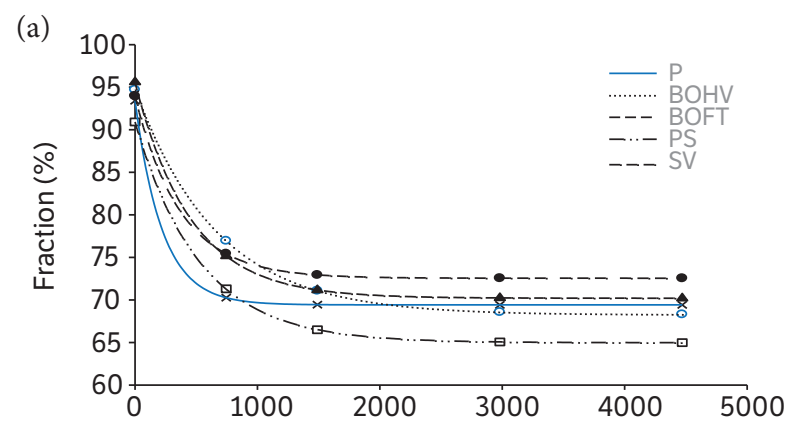

(b)

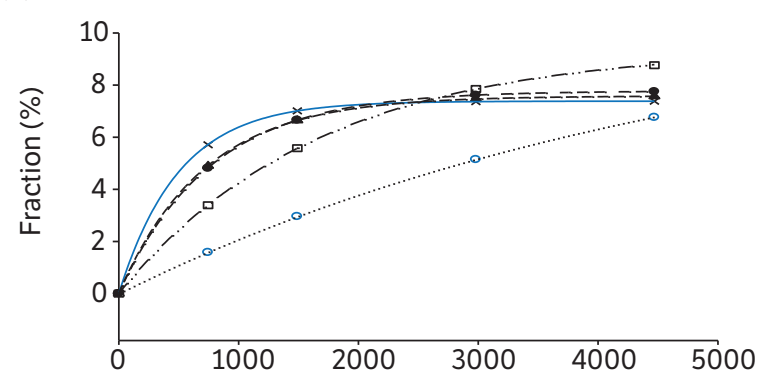

(c)

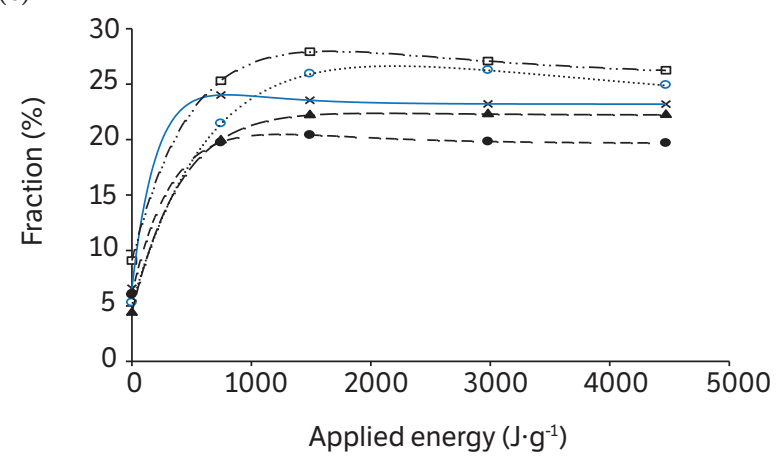

Figure 2. (a) Soil aggregate-disruption characteristic curve-ADCC; (b) soil-dispersion characteristic curve-SDCC; and C) the releasing of aggregate and dispersion curve-RADC. predicting in what level of energy occurred the release and dispersion of clay.

The higher values of the constants $\mathrm{k}_{1}$ and $\mathrm{k}_{2}$ show lower resistance to disaggregation, as higher values of CE indicate greater structural stability of soil aggregates (Zhu et al. 2009a; 2009b; 2010). In relation to the other management systems with cover crops, the increase in the value of $\mathrm{k}_{2}$ and the lowest CE $\left(324 \mathrm{~J} \cdot \mathrm{g}^{-1}\right)$ in the soil cultivated with $\mathrm{P}$ demonstrates greater release of aggregates in this management system when compared to the other cover crops. The aggregates of this management system are formed by weaker and less stable bonds (Zhu et al. 2010). These results may be due to the variation in the quality and degree of decomposition of the residue that is added to the soil by the cover plants. Remains of more easily decomposable crops, such as $\mathrm{P}$, exert a temporary effect on soil aggregation, while residues with lower decomposition rates exert a gradual and longer lasting effect on soil aggregation (Le Guillou et al. 2012). Legume plant residues decompose rapidly due to their low $\mathrm{C} / \mathrm{N}$ ratio (20), as they have high nitrogen and watersoluble carbon contents (Giacomini et al. 2004; 2003). Legumes (peanuts) release great part of nutrients during the first 30 days after shoot deposition in the soil (GamaRodrigues et al. 2007). The peanuts residues also have lower lignin content, which is reflected in lower values of the Cel/Lig and Lig/N ratio when compared to black oats. In residues with lower lignin content (peanuts), the cellulose of the cell wall has less mechanical protection against degradation (VanLauwe et al. 1997).

This behavior also occurs due to differences in the biological communities provided by each type of crop residue. In soils with higher lability residues, such as $\mathrm{P}$, communities of living organisms that excrete

Table 4. Estimated coefficients for the distribution models of aggregates as a function of the applied ultrasonic energy.

\begin{tabular}{|c|c|c|c|c|c|c|}
\hline \multirow{2}{*}{ Management } & $a_{2}$ & $y_{0}$ & $a_{1}$ & $k_{2}^{*}$ & $\mathbf{k}_{1}^{*}$ & \multirow{2}{*}{$\begin{array}{c}C E \\
\left(J \cdot g^{-1}\right)\end{array}$} \\
\hline & \multicolumn{3}{|c|}{$\left(\mathrm{dag} \cdot \mathrm{kg}^{-1}\right)$} & \multicolumn{2}{|c|}{$\left(g \cdot J^{-1}\right)$} & \\
\hline BOFT & 7.5816 & 70.2028 & 25.4027 & $0.0014 a b$ & $0.0022 b$ & $564 c$ \\
\hline BOHV & 11.4711 & 68.2759 & 26.4203 & $0.0002 c$ & $0.0015 b$ & $1549 a$ \\
\hline PS & 9.431 & 64.9775 & 25.935 & $0.0006 \mathrm{bc}$ & $0.0019 b$ & $886 b$ \\
\hline$P$ & 7.3831 & 69.4193 & 23.9967 & $0.002 a$ & $0.0045 a$ & $324 d$ \\
\hline SV & 7.7756 & 72.5539 & 21.4258 & $0.0013 a b$ & $0.0027 b$ & $522 c$ \\
\hline
\end{tabular}

$\mathrm{BOFT}=$ black oat + forage turnip; $\mathrm{BOHV}=$ black oat + hairy vetch $(\mathrm{BOHV}) ; \mathrm{PS}=$ Perennial soybean; $\mathrm{P}=$ peanuts; $\mathrm{SV}=\mathrm{spontaneous} \mathrm{vegetation;} \mathrm{CE} \mathrm{=} \mathrm{critical}$ energy. ${ }^{\star}$ Means followed by the same letter in the column do not differ from each other by the Tukey test $(p<0.05)$. 
polysaccharides and sugars during the decomposition process are favored. Under these conditions, weak binding agents form the aggregates, exhibiting low stability (Zhu et al. 2017).

However, aggregates formed by the decomposition of residues with a higher $\mathrm{C} / \mathrm{N}$ ratio, such as the $\mathrm{BOHV}$ treatment (Giacomini et al. 2004), are preferentially stabilized by living organisms that develop on more recalcitrant substrates. As the products from the decomposition of lower lability residues are lignins and polyphenols, it is possible that these cementing agents constituted aggregates with stronger and more persistent bonds (Le Guillou et al. 2012).

The assumptions of the models of Field and Minasny (1999) propose that there is a hierarchy among the fractions when the disaggregation constant $\left(\mathrm{k}_{1}\right)$ is greater than that of the dispersion constant $\left(\mathrm{k}_{2}\right)$. Under these conditions, the release rate of the aggregates is greater than the dispersion rate, indicating that the bonds between the microaggregates released in the RADC are weaker than the bonds within the material forming the microaggregates.

The inflection (peak) in the RADC of all the treatments (Fig. 2) is not as pronounced as those observed by others authors for soils of temperate regions (Zhu et al. 2010). This happened because there was no significant difference between the constants $k_{1}$ and $k_{2}$. The greater the difference between the constants, the more expressive is the inflection in the RADC (Field and Minasny 1999; Zhu et al. 2010). However, $\mathrm{k}_{1}$ is larger than $\mathrm{k}_{2}$ (Table 4), showing that this soil presents aggregate hierarchy, certainly as a function of organic matter.

Aggregate hierarchy has been observed in soils where organic matter is the main agent of stabilization of aggregates (Zhu et al. 2010). However, the hierarchical model of aggregation has not been valid for soils where $\mathrm{Fe}$ and $\mathrm{Al}$ oxides assume the main role in stabilizing soil aggregates (Ribeiro et al. 2013; Zhu et al. 2010).

\section{CONCLUSION}

Cover crops influence on the critical energy levels required for dispersion of aggregates of a Typic Hapludalf, but it was not proved that management systems with intercrops of the cover crops, as black oats and vetch, contribute more effectively to the increase of soil aggregation.

The conservation management with black oats and vetch increased the soil structural stability, which was expressed by the increment of the CE, and lower NDI and b/a index.

The increase in the value of the constant $\mathrm{k}_{2}$ and the lower CE (324 J.g $\left.\mathrm{g}^{-1}\right)$ in the soil cultivated with the forage peanut demonstrated that the rate of release of aggregates is faster than in the soil under spontaneous vegetation, black oats and hairy vetch, black oats and forage turnip, perennial soybean management systems.

\section{AUTHOR'S CONTRIBUTION}

Conceptualization, Silva, É. A., Reinert, D., Reichert J.M., Mallmann, M.S., Pereira M.A., Pons S.S. and Foggiato W.S; Investigation, Silva, É. A., Reinert, D., Reichert, J.M., Mallmann, M.S; Writing - Original Draft, Silva, É. A., Reinert, D., Reichert J.M., Mallmann, M.S., Pereira M. A., Pons S.S. and Foggiato W.S; Writing - Review and Editing, Silva, É. A., Reinert, D., Reichert J.M., Mallmann, M.S.; Supervision, Reinert, D., Reichert J.M.

\section{ORCID IDS}
É. A. Silva
(D) https://orcid.org/0000-0002-4718-2716
D.J. Reinert
(iD) https://orcid.org/0000-0002-4671-8486
J. M. Reichert
(D) https://orcid.org/0000-0001-9943-2898
M. S. Mallmann
(D) https://orcid.org/0000-0003-0179-6031
M. A. Pereira
https://orcid.org/0000-0001-9890-2579
S. S. Pons
(D) https://orcid.org/0000-0003-4735-1927
W. S. Foggiato
(D) https://orcid.org/0000-0002-0084-4807 


\section{REFERENCES}

Acosta, J. A. A., Amado, T. J. C., Silva, L. S., Santi, A. and Weber, M. A. (2014). Fitomass decomposition and nitrogen release of cover crops in function of the level of residue input to soil under no-tillage system. Ciência Rural, 44, 801-809. https://doi.org/10.1590/ S0103-84782014005000002

Aita, C. and Giacomini, S. J. (2003). Decomposição e liberação de nitrogênio dos resíduos culturais de plantas de cobertura solteiras e consorciadas. Revista Brasileira Ciência do Solo, 27, 601-612. https://doi.org/10.1590/S0100-06832003000400004

Briedis, C., Moraes, J. C. S., Caires, E. F., Navarro, J. D. F., Inagaki, T. M., Boer, A., Neto, C. Q., Ferreira, A. D. O., Canalli, L. B. and Santos, J. B. (2012). Soil organic matter pools and carbon-protection mechanisms in aggregate classes influenced by surface liming in a no-till system. Geoderma, 170, 80-88. https://doi.org/10.1016/j. geoderma.2011.10.011

Doneda, A., Aita, C., Giacomini, S. J., Miola, E. C. C., Giacomini, D. A., Schirmann, J. and Gonzatto, R. (2012). Fitomassa e decomposição de resíduos de plantas de cobertura puras e consorciadas. Revista Brasileira de Ciência do Solo, 36, 1714-1723. https://doi.org/10.1590/ S0100-06832012000600005

Espindola, J. A. A., Guerra, J. G. M., De-Polli H., Almeida, D. L. and Abboud, A. C. S. (2005). Adubação verde com leguminosas. Brasília: Embrapa Informação Tecnológica.

Field, D. J. and Minasny, B. (1999). A description of aggregate liberation and dispersion in A horizons of Australian vertisols by ultrasonic agitation. Geoderma, 91, 11-26. https://doi.org/10.1016/ S0016-7061(98)00142-6

Field, D. J., Minasny, B. and Gaggin, M. (2006). Modelling aggregate liberation and dispersion of three soil types exposed to ultrasonic agitation. Australian Journal of Soil Research, 44, 497-502. https:// doi.org/10.1071/SR05127

Gama-Rodrigues, A. C., Gama-Rodrigues, E. F. and Brito, E. C. (2007). Decomposition and nutrient release from cover crop residues in passion-fruit plantation. Revista Brasileira de Ciência do Solo, 31, 1421-1428. https://doi.org/10.1590/S0100-06832007000600019

Giacomini, S. J., Aita, C., Chiapinotto, I. C., Hübner, A. P., Marques, M. G. and Cadore, F (2004). Consorciação de plantas de cobertura antecedendo o milho em plantio direto. II-Nitrogênio acumulado pelo milho e produtividade de grãos. Revista Brasileira de Ciência do Solo, 28,751-762. https://doi.org/10.1590/S0100-06832004000400015
Giacomini, S. J., Aita, C., Vendruscolo, E. R. O., Cubilla, M., Nicoloso, R.S. and Fries, M. R. (2003). Matéria seca, relação C/N e acúmulo de nitrogênio, fósforo e potássio em misturas de plantas de cobertura de solo. Revista Brasileira de Ciência do Solo, 27, 325-334. https:// doi.org/10.1590/S0100-06832003000200012

Kaiser, M. and Berhe, A. A. (2014). How does sonication affect the mineral and organic constituents of soil aggregates? A review. Journal of Plant Nutrition and Soil Science, 177, 479-495. https:// doi.org/10.1002/jpln.201300339

Lal, R. (2015). Soil carbon sequestration and aggregation by cover cropping. Journal of Soil and Water Conservation, 70, 329-339. https://doi.org/10.2489/jswc.70.6.329

Le Guillou, C., Angers, D., Leterme, P. and Menasseri-Aubry, S. (2012). Changes during winter in water stable aggregation due to crop residue quality. Soil Use and Management, 28, 590-595. https://doi.org/10.1111/j.1475-2743.2012.00427.x

R Core Team (2014). R: A language and environment for statistical computing. Vienna: R Foundation for Statistical Computing.

Ribeiro, B. T., Lima, J. M., Curi, N. and Oliveira, G. C. (2013). Aggregate breakdown and dispersion of soil samples amended with sugarcane vinasse. Scientia Agricola, 70, 435-441. https:// doi.org/10.1590/S0103-90162013000600009

Ribeiro, B. T., Lima, J. M., Oliveira, G. C., Curi, N., Silva, E. A. and Silva, B. M. (2017). Ultrasonic aggregate breakdown of an Oxisol as affected by cavitation intensity. Communications in Soil Science and Plant Analysis, 48, 818-824, https://doi.org/10.1080/001036 24.2017.1299170

Sá, M. A. C., Lima, J. M. and Mello, C. R. (2002). Níveis de energia ultra-sônica para estudo da estabilidade de agregados de um Latossolo sob diferentes usos. Pesquisa Agropecuária Brasileira, 37,1649-1655. https://doi.org/10.1590/S0100-204X2002001100017

Sá, M. A. C., Lima, J. M., Silva, M. L. N. and Dias Júnior, M. S.(1999). Índices de desagregação do solo baseado em energia ultrasônica. Revista Brasileira de Ciência do Solo, 23, 525-531. https:// doi.org/10.1590/S0100-06831999000300005

Schomakers, J., Mentler, A., Steurer, T., Klik, A. and Mayer, H. (2011). Characterization of soil aggregate stability using low intensity ultrasonic vibrations. International Agrophysics, 25, 165-72. 
Silva, É. A., Oliveira, G. C., Carducci, C. E., Lima, J. M., Melo, L. B. B. and Benevenute, P. A. N. (2016). Stability of soil aggregates in latosols and cambisols via standard method and sonification. African Journal of Agricultural Research, 11, 3894-3903. https:// doi.org/10.5897/AJAR2016.11192

Tisdall, J. M. and Oades, J. M. (1982). Organic matter and waterstable aggregates in soils. The Journal of Soil Science, 33, 141-163. https://doi.org/10.1111/j.1365-2389.1982.tb01755.x

Tivet, F., Moraes, J. C. S., Lal, R., Briedis, C., Borszowskei, P. R., Santos, J. B., Farias, A., Eurich, G., Hartman, D. C., Nadolny Junior, M., Bouzinac, S. and Séguy, L. (2013). Aggregate C depletion by plowing and its restoration by diverse biomass- $\mathrm{C}$ inputs under no-till in sub-tropical and tropical regions of Brazil. Soil Tillage Research, 126, 203-218. https://doi.org/10.1016/j.still.2012.09.004 VanLauwe, J. D., Sanginga, N. and Merckx, R. (1997). Residue quality and decomposition: an unsteady relationship? In G.
Cadisch and K. E. Giller (Eds.), Driven by nature-plant letter quality and decompositions (p. 157-166). Wallingford: CAB International.

Zhu, Z., Angers, D. A., Field, D. J. and Minasny, B. (2017). Using ultrasonic energy to elucidate the effects of decomposing plant residues on soil aggregation. Soil and Tillage Research, 167, 1-8. https://doi.org/10.1016/j.still.2016.10.002

Zhu, Z., Minasny, B., and Field, D. J. (2009a). Adapting technology for measuring soil aggregate dispersive energy using ultrasonic dispersion. Biosystems Engineering, 104, 258-265. https://doi. org/10.1016/j.biosystemseng.2009.06.011

Zhu, Z., Minasny, B. and Field, D. J. (2009b). Measurement of aggregate bond energy using ultrasonic dispersion. European Journal Soil Science, 60, 695-705. https://doi. org/10.1111/j.1365-2389.2009.01146.x

Zhu, Z., Field, D. and Minasny, B. (2010). Measuring and modeling the actual energy involved in aggregate breakdown. Catena, 82, 53-60. https://doi.org/10.1016/j.catena.2010.04.009 